\title{
Preliminary inventory of mammals from Yurubí National Park, Yaracuy, Venezuela with some comments on their natural history
}

\author{
Franger J. García ${ }^{1,2}$, Mariana Delgado-Jaramillo ${ }^{1,2}$, Marjorie Machado ${ }^{1} \&$ Luis Aular $^{2}$ \\ 1. Departamento de Biología, Facultad Experimental de Ciencias y Tecnología (FACYT), Universidad de Carabobo; \\ cormura@yahoo.com,marianadelgado13@yahoo.es,mmachado3@uc.edu.ve \\ 2. Grupo de Exploraciones Científicas Minas de Aroa, Yaracuy (GECMA-Yaracuy); guacharocuy@hotmail.com
}

\author{
Received 22-IX-2010. C Corrected 20-V-2011. Accepted 21-VI-2011.
}

\begin{abstract}
In Venezuela, mammals represent an important group of wildlife with high anthropogenic pressures that threaten their permanence. Focused on the need to generate baseline information that allows us to contribute to document and conserve the richness of local wildlife, we conducted a mammalogical inventory in Yurubí National Park, located in Yaracuy State in Venezuela. We carried out fieldworks in three selected vegetation types: an evergreen forest at $197 \mathrm{~m}$, a semi-deciduous forest ranging between 100-230m, and a cloud forest at $1446 \mathrm{~m}$. We used Victor, Sherman, Havahart and pitfall traps for the capture of small non-volant mammals and mist nets for bats. In addition, we carried out interviews with local residents and direct-indirect observations for medium-large sized mammals. At least 79 species inhabit the area, representing $28 \%$ of the species recorded for the North side of the country. Chiroptera (39 spp.), Carnivora (13 spp.) and Rodentia ( 9 spp.) were the orders with the highest richness, as expected for the Neotropics. The evergreen forest had the greatest species richness $(n=68)$, with a sampling effort of 128 net-hours, 32 bucket-days, 16 hours of observations, and three persons interviewed, followed by cloud forest $(n=45)$ with 324 net-hours, 790 traps-night, 77 bucket-days, 10 hours of observations, and one person interviewed. The lowest richness value was in the semi-deciduous forest $(n=41)$, with 591 traps-night, 15 net-hours, 10 hours of observations and three persons interviewed. Data and observations obtained in this inventory (e.g., endemism, species known as "surrogate species" threatened in Venezuela) give an important role at the Yurubí National Park in the maintenance and conservation of local ecosystems and wildlife, threatened by human pressures in the Cordillera de la Costa. Rev. Biol. Trop. 60 (1): 459-472. Epub 2012 March 01.
\end{abstract}

Key words: inventory, mammals, Sierra de Aroa, Venezuela, Yurubí National Park.

In Venezuela, mammals represent the second richest group of terrestrial vertebrates, after birds (Hilty et al. 2003, Ochoa \& Aguilera 2003). Linares (1998) documented 327 species included in 12 orders and 42 families. Later, Ochoa \& Aguilera (2003) reported 351 species in 13 orders and 43 families and this number has increased in recent years thanks to taxonomic contributions and new descriptions (e.g., Anderson 2003, Lew \& Pérez-Hernández 2004, Sánchez et al. 2005, Lew et al. 2006, Weskler et al. 2006, Molinari 2007, Gutiérrez \& Molinari 2008). The current checklist based on Wilson $\&$ Reeder (2005) and supported with additional publications (e.g., Gardner 2008, Dávalos \& Corthals 2008, Gutiérrez \& Molinari 2008, Ochoa et al. 2008, Anderson \& Gutiérrez 2009) increases the number to 383 species into 14 orders and 47 families with 25 endemic species in six orders: Didelphimorphia, Carnivora, Lagomorpha, Soricomorpha, Chiroptera, Artiodactyla and Rodentia (Linares 1998, Ochoa \& Aguilera 2003, Wilson \& Reeder 2005, Lew et al. 2006, Molinari 2007, Gardner 2008, Gutiérrez \& Molinari 2008, Anderson \& Gutiérrez 2009, Helgen et al. 2009).

Currently, Venezuela has 43 National Parks of which 23 have mammalogical records 
(Handley 1976, Valdez et al. 1984, Ochoa 1986, Gardner 1988, Guerrero et al. 1989, Fernández-Badillo \& Ulloa 1990, Ochoa \& Gorzula 1992, Ojasti et al. 1992, Ochoa et al. 1993, 1995, 2000, 2005, Bisbal 1995, 1998, 2008, Soriano et al. 1990, 1999, Linares \& Rivas 2003, MARN 2003, 2005, Rivas \& Salcedo 2005, Lew et al. 2009).

Regarding the Yurubí National Park, there is no inventory linked with mammals, and the only mammalogical survey close to the study area was the expedition between 1965-1968 by the Smithsonian Venezuelan Project (Handley 1976), in the locality called "Minas de Aroa" in the Sierra de Aroa, where the Yurubí National Park is located. Much of the surface of the Sierra de Aroa is fragmented by farming, and perhaps the only area that has not been affected is the Yurubí National Park, due to its status of protected area (Lentino \& Esclasans 2005).

Taxonomic studies of other vertebrates in localities of the Sierra de Aroa and in the Yurubí National Park have resulted in descriptions of new endemic species: a highland forest frog (Dendropsophus yaracuyanus Mijares-Urrutia
\& Rivero 2000); a caecilian (Caecilia flavopuntacta Roze \& Solano 1963), and 10 fishes (Rodríguez-Olarte et al. 2005). For Yurubí vegetation, there is endemism reported in some plant species in families Rubiaceae: Hoffmania aroensis, H. stenocarpa and Piperaceae: Piperomia croizatiana (Delascio 1977).

Because there is a lack of mammalogical information in Yurubí National Park, added to anthropogenic pressures that threaten the permanence of species that inhabit the mountain regions in Cordillera de la Costa (Ochoa et al. 1995, Rodríguez \& Rojas 1998), here, we present the preliminary results of an inventory focused on the need to generate baseline information as an effort to contribute with some information and to stimulate the conservation of local wildlife.

\section{MATERIALS AND METHODS}

Study Area: The Yurubí National Park is located in the Sierra de Aroa, Yaracuy State, Venezuela (Fig. 1). It has a surface of 23 670ha

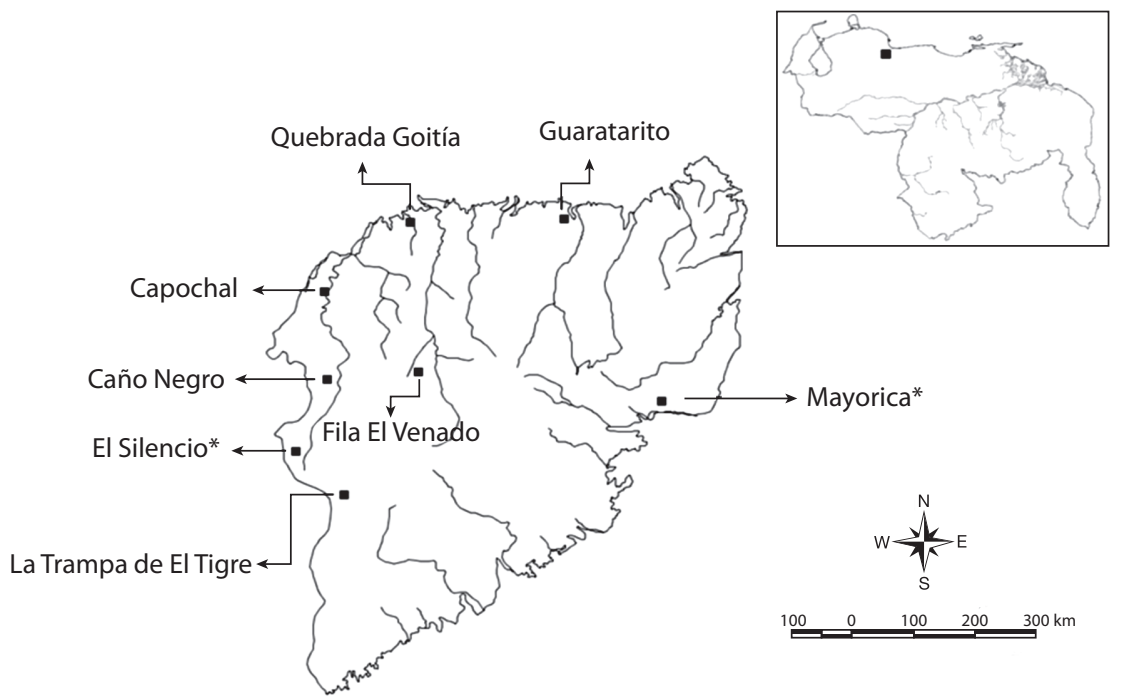

Fig. 1. Geographical location of Yurubí National Park, showing the sampled localities in this inventory with an asterisk (*): "Mayorica" $\left(10^{\circ} 26^{\prime} \mathrm{N}-68^{\circ} 40^{\prime} \mathrm{W}\right)$ and "El Silencio" $\left(10^{\circ} 25^{\prime} \mathrm{N}-68^{\circ} 48^{\prime} \mathrm{W}\right)$. Voucher specimens of another localities previous to this study are deposited in EBRG: Guaratarito (10 $\left.30^{\prime} \mathrm{N}-68^{\circ} 42^{\prime} \mathrm{W}\right)$, Quebrada Goitía $\left(10^{\circ} 30^{\prime} \mathrm{N}-6^{\circ} 46^{\prime} \mathrm{W}\right)$,

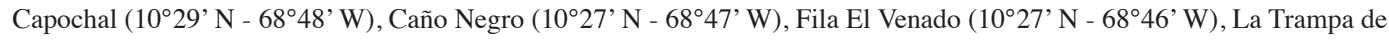
El Tigre $\left(10^{\circ} 24^{\prime} \mathrm{N}-68^{\circ} 47^{\prime} \mathrm{W}\right)$. 
(Lentino \& Esclasans 2005) and an altitudinal range between $100-1940 \mathrm{~m}$. The climate is seasonal and macrothermic, with an average annual precipitation between $800-1500 \mathrm{~mm}$ and a bimodal temporal distribution with a rainy season in July-August and other in NovemberDecember (Alvarado 2008). The annual average temperature is between $10-26.5^{\circ} \mathrm{C}$.

Data acquisition: The first step of this survey was the collection of all information on mammals from specimens deposited in national institutions (museums and universities) and literature review. The second step consisted of three field expeditions, beginning on August 29- September 62008 , for the locality called "Mayorica" (10²6' N - 6840' W; 100-230m), and we then carried out two expeditions on February 6-14 2009 and May 16-21 2009, in the locality "El Silencio" $\left(10^{\circ} 25^{\prime} \mathrm{N}-68^{\circ} 48^{\prime}\right.$ $\mathrm{W} ; 1446 \mathrm{~m})$. The fieldwork consisted of seven days for "Mayorica" and six days for "El Silencio", with nights with limited moonlight.

We selected three vegetation types in Yurubí National Park: an evergreen forest at $197 \mathrm{~m}$, located in "Mayorica". The understory was open with the families Palmae (e.g., Geonoma sp., Euterpe longiptiolata and Chamaedorea sp.), Melastomataceae, Piperaceae and Rubiaceae, being the most observed in the lower stratum. In watercourses, we noted Heliconiaceae (e.g., Heliconia psittacorum and H. bihai), Acanthaceae, Poaceae (e.g., Olyra sp.), Arecaceae and Haemodoraceae (e.g., Xiphidium caeruleum). Trees included Ficus spp. (Moraceae), Gyranthera caribensis (Malvaceae), Pachira aquatica (Bombacaceae), Clusia sp. (Guttiferae), Lecythis ollari (Lecythidaceae), Inga sp. (Leguminosae), Ocotea sp. (Lauraceae) and Brownea grandiceps (Fabaceae) among others. Epiphytism was represented by Bromeliaceae (e.g., Guzmania), Orchidaceae (e.g., Epidendrum and Eulophidium) and Araceae (e.g., Philodendron).

We selected within this same locality a strip of semi-deciduous forest ranging 100-213m, and here, trees belonging to the following genera: Bursera (Burseraceae), Hura (Euphorbiaceae),
Ceiba (Bombacaceae), Cedrela (Meliaceae), Ceroxilum (Arecaceae), Tabebuia (Bignoniaceae) and Spondias (Anacardiaceae) were the best represented; in addition Leguminosae, Araceae, Selagineceae, abundant lianas and epiphytes in the lower stratum.

The last site chosen was a cloud forest at $1446 \mathrm{~m}$ in "El Silencio". The following plant genera were the most common in this locality: Persea, Clusia, Guarea, Sapium, Lecythis, Calatea, Ficus, Podocarpus, Brosimum, Gustavia, Gyranthera, Oliganthes, Catoblastus, Guzmania, Cecropia and Cyathea belonging to the families Lauraceae, Guttiferae, Meliaceae, Euphorbiaceae, Lecythidaceae, Marantaceae, Moraceae, Podocarpaceae, Arecaceae, Malvaceae, Asteraceae, Bromeliaceae, Urticaceae and Cyatheaceae.

Capture of small non-volant mammals: We set four types of traps following of Ochoa et al. (2008) recommendations.

1) Victor traps, were placed on the ground and heights ranging from $1-2 \mathrm{~m}$ for the capture of taxa using the ground (terrestrial) and the middle stratum (arboreal). 2) Sherman live traps, were placed on the ground level to capture terrestrial taxa. 3) Havahart live traps were placed on the ground to capture terrestrial taxa and 4) a pitfall-trap system to capture of terrestrial and semi-arboreal taxa. All traps, except the pitfall-trap system, were baited daily with some of the following baits: 1) a mixture of oats, sardines, oil and vanilla extract). 2) ripe plantain (Musa sp.) and 3) food for birds (canary seed). These traps were placed at approximately $20 \mathrm{~m}$ intervals along existing trails, and the pitfall-trap system was placed at ground level and it was spaced $5 \mathrm{~m}$ apart every plastic buckets with a fence in a linear series. Total traps (Victor, Sherman and Havahart), used were 80 and the total sampling effort was 1382 trap-nights and 109 bucket-days.

Capture of bats: The procedure followed Ochoa et al. (2008). We set three mist nets of $9 \mathrm{~m}$ and three mist nets of $12 \mathrm{~m}$ in different forest strata (understory and mid-canopy). Mist 
nets were activated from 18:00-22:00 hours and in some occasions from 04:00-06:00 hours in order to cover two major peaks of activity. In addition to we carried out occasional searches of shelters in the daytime (e.g., caves, crevices, foliage, hollows in trees and logs, etc.). The total sampling effort was 323 net-hours.

Medium-large sized mammals: To record medium-large sized mammals (e.g., Carnivora, Artiodactyla, Perissodactyla and Rodentia), we used a field guide to interview local residents together with our direct and indirect sightings (e.g., tracks, vocalizations and scats). We interviewed seven persons and we carried out 36 hours of observations.

Identifications followed Wilson \& Reeder (2005) and Gardner (2008) for most species, Weksler et al. (2006) for Oryzomyini, Larsen et al. (2007) for large-sized Artibeus, Lim et al. (2008) for small-sized Artibeus and Voss \& Jansa (2009) for didelphid marsupials. We followed guidelines approved by Gannon et al. (2007), for animals captured in the field. Voucher specimens were fixed in $10 \%$ formalin and preserved in $70 \%$ ethanol, and are deposited at the Museo de la Estación Biológica de Rancho Grande (EBRG-Maracay) and Museo de Zoología (MZUC), Departamento de Biología, Facultad Experimental de Ciencias y Tecnología FACYT, Universidad de Carabobo, Valencia, Carabobo State, Venezuela.

\section{RESULTS}

At least 79 species, representing 10 orders inhabit in the study area (Table 1). Of these, $73 \%(n=58)$ represent new records in Yurubí

TABLE 1

Mammals recorded in Yurubí National Park, Yaracuy State, Northern Venezuela

\begin{tabular}{lccc}
\multicolumn{1}{c}{ TAXA } & SDF & Eegetation types & Threat \\
Categories
\end{tabular}


TABLE 1 (Continued)

Mammals recorded in Yurubí National Park, Yaracuy State, Northern Venezuela

\begin{tabular}{|c|c|c|c|c|}
\hline \multirow{2}{*}{ TAXA } & \multicolumn{3}{|c|}{ Vegetation types } & \multirow{2}{*}{$\begin{array}{c}\text { Threat } \\
\text { Categories }\end{array}$} \\
\hline & SDF & $\mathrm{EF}$ & $\mathrm{CF}$ & \\
\hline \multicolumn{5}{|l|}{ ATELIDAE } \\
\hline \multicolumn{5}{|l|}{ ALOUATTINAE } \\
\hline Alouatta seniculus ${ }^{5}$ & $\mathrm{O}, \mathrm{V}, \mathrm{I}$ & $\mathrm{BP}, \mathrm{O}, \mathrm{V}, \mathrm{I}$ & $\mathrm{V}, \mathrm{I}, \mathrm{BP}$ & \\
\hline \multicolumn{5}{|l|}{ LAGOMORPHA } \\
\hline \multicolumn{5}{|l|}{ LEPORIDAE } \\
\hline Sylvilagus brasiliensis & I & I & I & \\
\hline \multicolumn{5}{|l|}{ CHIROPTERA } \\
\hline \multicolumn{5}{|l|}{ EMBALLONURIDAE } \\
\hline \multicolumn{5}{|l|}{ EMBALLONURINAE } \\
\hline Peropteryx kappleri $^{7}$ & & $3 \mathrm{MR}$ & & \\
\hline Saccopteryx bilineata ${ }^{4}$ & & $1 \mathrm{MR}$ & & \\
\hline Saccopteryx leptura ${ }^{4}$ & & $1 \mathrm{R}$ & & \\
\hline \multicolumn{5}{|l|}{ PHYLLOSTOMIDAE } \\
\hline \multicolumn{5}{|l|}{ DESMODONTINAE } \\
\hline Desmodus rotundus ${ }^{8}$ & & $\mathrm{O}, \mathrm{I}$ & & \\
\hline Diphylla ecaudata ${ }^{4}$ & & $1 \mathrm{C}$ & & DD \\
\hline \multicolumn{5}{|l|}{ GLOSSOPHAGINAE } \\
\hline Anoura cultratra ${ }^{4}$ & & & $1 \mathrm{MR}$ & \\
\hline Glossophaga soricina ${ }^{4}$ & $2 \mathrm{C}$ & $4 \mathrm{C}, 3 \mathrm{MR}$ & $1 \mathrm{MR}$ & \\
\hline \multicolumn{5}{|l|}{ PHYLLOSTOMINAE } \\
\hline Chrotopterus auritus $^{4}$ & & $1 \mathrm{C}$ & & \\
\hline Lonchorhina aurita ${ }^{4,8}$ & & $4 \mathrm{C}, 1 \mathrm{R}, \mathrm{O}, 2 \mathrm{MR}$ & & \\
\hline Lophostoma silvicolum ${ }^{4}$ & & $1 \mathrm{C}$ & & \\
\hline Micronycteris hirsuta ${ }^{6}$ & & $1 \mathrm{MR}$ & & \\
\hline Micronycteris megalotis ${ }^{4}$ & $1 \mathrm{C}$ & & $2 \mathrm{MR}$ & \\
\hline Micronycteris microtis ${ }^{4}$ & & $2 \mathrm{C}$ & & \\
\hline Micronycteris minuta ${ }^{4}$ & & $1 \mathrm{C}$ & & \\
\hline Mimon crenulatum ${ }^{4}$ & & $1 \mathrm{C}$ & & \\
\hline Phylloderma stenops ${ }^{4}$ & & $1 \mathrm{C}$ & & \\
\hline Phyllostomus discolor ${ }^{4}$ & $1 \mathrm{C}$ & $3 \mathrm{MR}$ & & \\
\hline Phyllostomus hastatus ${ }^{4}$ & $1 \mathrm{C}$ & $1 \mathrm{MR}$ & & \\
\hline Tonatia saurophila ${ }^{4}$ & $1 \mathrm{C}$ & $1 \mathrm{C}$ & & \\
\hline Trachops cirrhosus ${ }^{1,4}$ & & $1 \mathrm{C}$ & & \\
\hline \multicolumn{5}{|l|}{ CAROLLIINAE } \\
\hline Carollia brevicauda ${ }^{4}$ & & $2 \mathrm{C}, 1 \mathrm{R}, 2 \mathrm{MR}$ & $2 \mathrm{C}, 2 \mathrm{MR}, 2 \mathrm{R}$ & \\
\hline Carollia perspicillata $^{4,8}$ & $8 \mathrm{R}$ & 6C, 7MR, 61R & & \\
\hline \multicolumn{5}{|l|}{ STENODERMATINAE } \\
\hline Artibeus bogotensis ${ }^{4}$ & & $6 \mathrm{C}, 1 \mathrm{MR}$ & & \\
\hline Artibeus lituratus ${ }^{4}$ & $1 \mathrm{C}$ & $2 \mathrm{C}, 5 \mathrm{R}$ & $8 \mathrm{C}, 2 \mathrm{R}$ & \\
\hline Artibeus planirostris $^{4}$ & $2 \mathrm{C}, 9 \mathrm{R}$ & $4 \mathrm{C}, 18 \mathrm{R}$ & $7 \mathrm{C}, 6 \mathrm{R}$ & \\
\hline Chiroderma villosum ${ }^{4}$ & & $1 \mathrm{C}$ & & \\
\hline Platyrrhinus helleri ${ }^{4}$ & $1 \mathrm{C}$ & $3 \mathrm{C}$ & & \\
\hline Platyrrhinus umbratus ${ }^{4}$ & & & $8 \mathrm{MR}$ & $\mathrm{DD}$ \\
\hline
\end{tabular}


TABLE 1 (Continued)

Mammals recorded in Yurubí National Park, Yaracuy State, Northern Venezuela

\begin{tabular}{|c|c|c|c|c|}
\hline \multirow{2}{*}{ TAXA } & \multicolumn{3}{|c|}{ Vegetation types } & \multirow{2}{*}{$\begin{array}{c}\text { Threat } \\
\text { Categories }\end{array}$} \\
\hline & SDF & $\mathrm{EF}$ & $\mathrm{CF}$ & \\
\hline Platyrrhinus vittatus ${ }^{4}$ & & & $1 \mathrm{C}$ & \\
\hline Uroderma bilobatum ${ }^{4}$ & & $5 \mathrm{C}, 1 \mathrm{MR}, 2 \mathrm{R}$ & & \\
\hline Vampyressa thyone $e^{4}$ & & $2 \mathrm{C}$ & & \\
\hline Sturnira erythromos ${ }^{4}$ & & & $1 \mathrm{MR}$ & \\
\hline Sturnira lilium ${ }^{4}$ & $3 \mathrm{C}, 8 \mathrm{R}$ & $5 \mathrm{R}, 6 \mathrm{MR}$ & $2 \mathrm{C}, 1 \mathrm{MR}$ & \\
\hline Sturnira oporaphilum ${ }^{4}$ & & $1 \mathrm{C}, 2 \mathrm{MR}$ & $13 \mathrm{C}, 11 \mathrm{R}$ & \\
\hline \multicolumn{5}{|l|}{ MORMOOPIDAE } \\
\hline Pteronotus parnellii ${ }^{4}$ & & $2 \mathrm{MR}$ & $5 \mathrm{C}, 2 \mathrm{R}$ & \\
\hline Pteronotus personatus ${ }^{1,4}$ & & $1 \mathrm{C}$ & & \\
\hline \multicolumn{5}{|l|}{ VESPERTILIONIDAE } \\
\hline \multicolumn{5}{|l|}{ VESPERTILIONINAE } \\
\hline Eptesicus furinalis ${ }^{4}$ & $1 \mathrm{C}$ & $1 \mathrm{MR}$ & & \\
\hline Rhogeessa io ${ }^{4}$ & $1 \mathrm{C}$ & $2 \mathrm{C}$ & & \\
\hline \multicolumn{5}{|l|}{ MYOTINAE } \\
\hline Myotis keaysi ${ }^{4,8}$ & & $5 \mathrm{C}$ & $2 \mathrm{MR}$ & \\
\hline \multicolumn{5}{|l|}{ CARNIVORA } \\
\hline \multicolumn{5}{|l|}{ FELIDAE } \\
\hline \multicolumn{5}{|l|}{ FELINAE } \\
\hline Leopardus pardalis & I & I & I & $\mathrm{VU}$ \\
\hline Leopardus sp.(wiedii or tigrinus) & I & I & I & VU \\
\hline Puma concolor & I & I & I & NT \\
\hline Puma yagouaroundi ${ }^{2}$ & I & $\mathrm{O}, \mathrm{I}$ & I & \\
\hline \multicolumn{5}{|l|}{ PANTHERINAE } \\
\hline Panthera onca & I & $\mathrm{T}, \mathrm{I}$ & $\mathrm{T}, \mathrm{I}$ & VU \\
\hline \multicolumn{5}{|l|}{ CANIDAE } \\
\hline Cerdocyon thous & I & I & I & \\
\hline Speothos venaticus ${ }^{2}$ & & $\mathrm{O}$ & & $\mathrm{VU}$ \\
\hline \multicolumn{5}{|l|}{ MUSTELIDAE } \\
\hline \multicolumn{5}{|l|}{ MUSTELINAE } \\
\hline Eira barbara $^{2}$ & I & $\mathrm{O}$ & I & \\
\hline Mustela frenata & & & I & \\
\hline \multicolumn{5}{|l|}{ MEPHITIDAE } \\
\hline Conepatus semistriatus & I & I & I & \\
\hline \multicolumn{5}{|l|}{ PROCYONIDAE } \\
\hline Nasua nasua & I & I & & \\
\hline Procyon cancrivorus ${ }^{1,2}$ & I & $\mathrm{I}, \mathrm{FR}, \mathrm{O}, \mathrm{I}$ & I & \\
\hline Potos flavus 5 & I & $\mathrm{O}, \mathrm{V}, \mathrm{I}$ & $\mathrm{V}, \mathrm{I}$ & \\
\hline \multicolumn{5}{|l|}{ PERISSODACTYLA } \\
\hline \multicolumn{5}{|l|}{ TAPIRIDAE } \\
\hline Tapirus terrestris ${ }^{1,2}$ & & $\mathrm{~T}, \mathrm{~S}, \mathrm{I}$ & $\mathrm{T}, \mathrm{S}, \mathrm{I}$ & VU \\
\hline \multicolumn{5}{|l|}{ ARTIODACTYLA } \\
\hline \multicolumn{5}{|l|}{ TAYASSUIDAE } \\
\hline Pecari tajacu & $\mathrm{I}$ & $2 \mathrm{H}, \mathrm{I}$ & $\mathrm{I}$ & \\
\hline
\end{tabular}


TABLE 1 (Continued)

Mammals recorded in Yurubí National Park, Yaracuy State, Northern Venezuela

\begin{tabular}{|c|c|c|c|c|}
\hline \multirow{2}{*}{ TAXA } & \multicolumn{3}{|c|}{ Vegetation types } & \multirow{2}{*}{$\begin{array}{c}\text { Threat } \\
\text { Categories }\end{array}$} \\
\hline & SDF & $\mathrm{EF}$ & $\mathrm{CF}$ & \\
\hline Tayassu pecari & I & $\mathrm{I}$ & $\mathrm{I}$ & \\
\hline \multicolumn{5}{|l|}{ CERVIDAE } \\
\hline Mazama americana & I & I & $1 \mathrm{C}, \mathrm{I}$ & DD \\
\hline Odocoileus cariacou & & I & & \\
\hline \multicolumn{5}{|l|}{ RODENTIA } \\
\hline \multicolumn{5}{|l|}{ SCIURIDAE } \\
\hline \multicolumn{5}{|l|}{ SCIURINAE } \\
\hline Sciurus granatensis 4 & $\mathrm{O}, \mathrm{I}$ & $\mathrm{O}, \mathrm{I}$ & I & \\
\hline \multicolumn{5}{|l|}{ HETEROMYIDAE } \\
\hline \multicolumn{5}{|l|}{ HETEROMYINAE } \\
\hline Heteromys anomalus ${ }^{2}$ & $5 \mathrm{C}$ & $\mathrm{O}$ & & \\
\hline Heteromys catopterius ${ }^{2}$ & & & $4 \mathrm{C}$ & \\
\hline \multicolumn{5}{|l|}{ CRICETIDAE } \\
\hline \multicolumn{5}{|l|}{ SIGMODONTINAE } \\
\hline Nephelomys caracolus ${ }^{2}$ & & & $2 \mathrm{C}$ & \\
\hline Transandinomys talamancae ${ }^{2}$ & $1 \mathrm{C}$ & $1 \mathrm{C}$ & $10 \mathrm{C}$ & \\
\hline \multicolumn{5}{|l|}{ ERETHIZONTIDAE } \\
\hline Coendou prehensilis & I & I & I & \\
\hline \multicolumn{5}{|l|}{ DASYPROCTIDAE } \\
\hline Dasyprocta leporina & I & I & I & \\
\hline \multicolumn{5}{|l|}{ CUNICULIDAE } \\
\hline Cuniculus paca ${ }^{2}$ & I & $\mathrm{T}, \mathrm{I}$ & $\mathrm{BP}, \mathrm{I}$ & \\
\hline \multicolumn{5}{|l|}{ ECHIMYIDAE } \\
\hline \multicolumn{5}{|l|}{ EUMYSOPINAE } \\
\hline Proechimys guairae ${ }^{2}$ & I & $1 \mathrm{C}, \mathrm{O}, \mathrm{I}$ & & \\
\hline TOTAL & 41 & 68 & 45 & \\
\hline
\end{tabular}

Vegetation types in sampled days of this work are: SDF: semi-deciduous forest, EF: evergreen forest and CF: cloud forest. Abbreviations of methods for the recording are: I: Interviews with local residents, O: Observations by authors, C: Collected in this inventory, MR: Museum records, BP: Bone parts found, T: Tracks, FR: Food remains, S: Scats, V: vocalizations, H: Hunting and R: Released. Numbers indicate stratum of collection or observations: 1=Associated with watercourses, $2=$ Ground, $3=$ Liana, 4=Understory, 5=Canopy, $6=$ Hole in tree, $7=$ Crevices and $8=$ Caves. Threat categories in Venezuela are based in Rodríguez \& Rojas-Suárez (2008): Vu=Vulnerable, NT=Near threatened, DD=Data deficient.

National Park. Chiroptera (39 spp.), Carnivora (13 spp.) and Rodentia (9 spp.) were the orders with the highest taxonomic richness. Among the vegetation types sampled (Table 1), the evergreen forest $(n=67)$, had the highest richness, followed by the cloud forest $(n=45)$, and finally by the semi-deciduous forest $(n=41)$. Sampling efforts in every inventoried locality are shown in Table 2.
Species accumulation curves for taxa inventoried with traps (Didelphimorphia: family Didelphidae and Rodentia: families Sciuridae, Heteromyidae, Cricetidae and Echimyidae) and mist nets (Chiroptera) at different locations did not reach saturation (Fig. 2).

For Chiroptera, results indicated a high richness concentrated in Phyllostomidae $(74.36 \%)$, Emballonuridae (7.69\%) and 
TABLE 2

Sampling efforts in evaluated localities of Yurubí National Park, Yaracuy State, Northern Venezuela

\begin{tabular}{lccc} 
& \multicolumn{3}{c}{ Sampled Localities and effort } \\
\multicolumn{1}{r}{ Methods } & \multicolumn{1}{c}{ Mayorica } & El Silencio \\
& Semi-deciduous forest & Evergreen forest & Cloud forest \\
Traps & 591 trap-nights & - & 790 trap-nights \\
Mist nets & 15 net-hours & 128 net-hours & 180 net-hours \\
Pitfall system & - & 32 bucket-days & 77 bucket-days \\
Observations & 10 hours & 16 hours & 10 hours \\
Interviews & 3 persons & 3 persons & 1 person \\
\hline
\end{tabular}
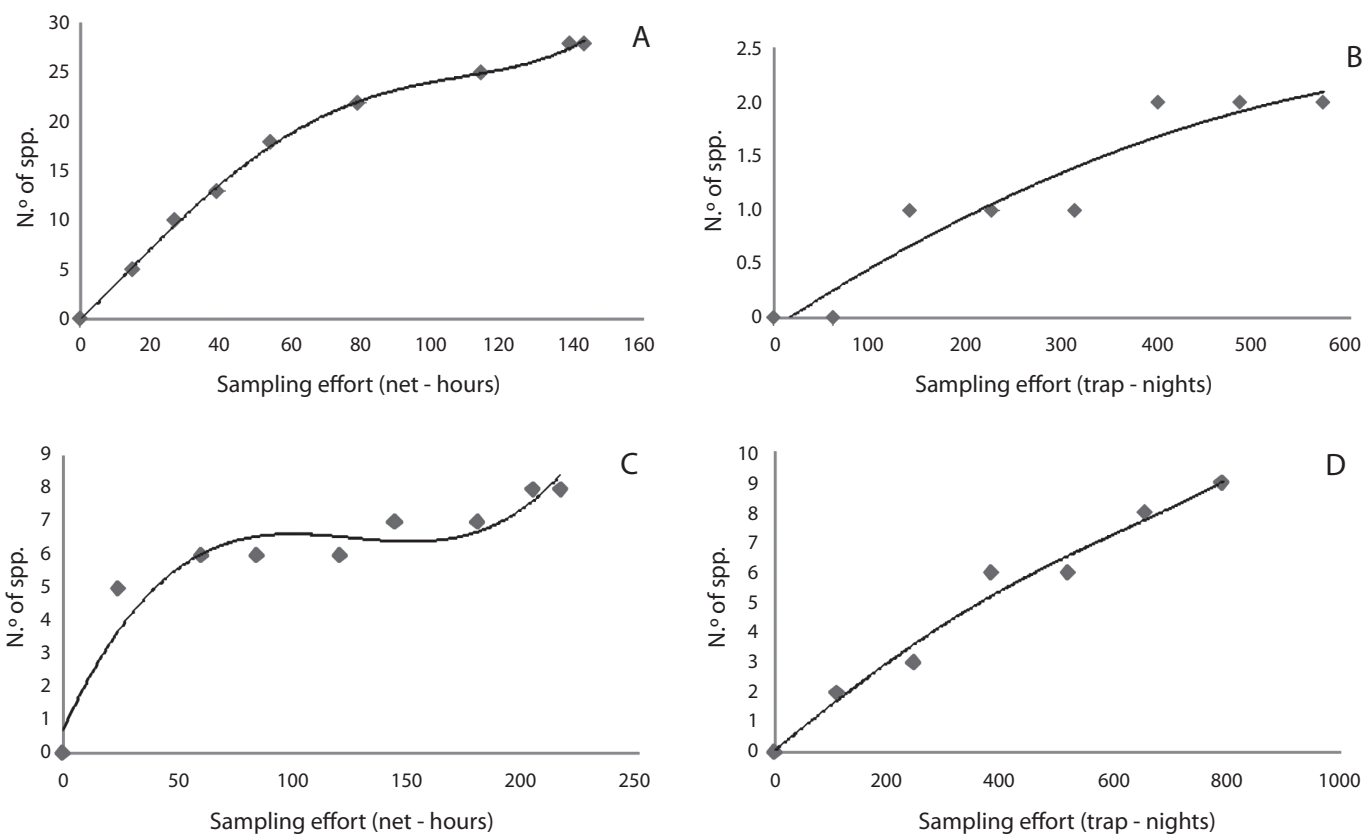

Fig. 2. Species accumulation curves for small mammals (marsupials, rodents and bats) inventoried in Yurubí National Park. (Above left) bats inventoried in Mayorica, (Above right) marsupials and rodents inventoried in Mayorica, (Bottom left) bats inventoried in El Silencio, (Bottom right) marsupials and rodents inventoried in El Silencio.

Mormoopidae (5.13\%) (Table 1). Noteworthy records of foliage gleaning bats (e.g., Micronycteris hirsuta, M. megalotis, M. microtis, M. minuta, Lonchorhina aurita, Mimon crenulatum, Tonatia saurophila and Lophostoma silvicolum) were obtained in this study (Table 1). There were no representatives of Molossidae (free-tailed bats), Natalidae (funnel-eared bats) and Thyropteridae (disk-winged bats), documented in other localities of the Sierra de Aroa and Cordillera de la Costa.

Rodents captured (Transandinomys talamancae, Heteromys anomalus, $H$. catopterius, Nephelomys caracolus and Proechimys guairae) represented important records for the mammalian fauna from Yurubí National Park. Of these, the latter three species were endemics (Heteromys catopterius endemic in the 
Cordillera de la Costa, Nephelomys caracolus endemic for the Cordillera de la Costa and Sierra de San Luis and Proechimys guairae endemics for five bioregions in Northern Venezuela).

Marsupials documented were Didelphis marsupialis, Marmosa demererae, Marmosops fuscatus, Chironectes minimus and Monodelphis palliolata (Table 1). The first three taxa with semi-arboreal habits; Chironectes, a terrestrial species associated with watercourses and Monodelphis, fully terrestrial. All these were captured and observed in primary habitats in Yurubí National Park.

We recorded 10 species assigned in some threat category for the country (Table 1). This number includes six species "Vulnerable", one "Near threatened" and three with "Data deficient". It is interesting to mention those mammals, such as monkeys (e.g., Alouatta seniculus and Cebus olivaceus), carnivores (e.g., Conepatus semistriatus, Cerdocyon thous, Potos flavus and Procyon cancrivorus) and the tapir (Tapirus terrestris), were apparently common, according to the interviews and occasional records in the study area. Another situation occurs for the paca (Cuniculus paca), peccaries (Tayassu pecari and Pecari tajacu), agouti (Dasyprocta leporina), deer (Mazama americana and Odocoileus cariacou), cats (Panthera onca, Puma concolor) and rabbits (Sylvilagus brasiliensis), which are the mainly hunted mammals, according to local residents.

From the total of mammals listed, 15 taxa have their restricted distributions in Northern Venezuela: Marmosops fuscatus, Monodelphis palliolata, Diphylla ecaudata, Anoura cultrata, Lonchorhina aurita, Sturnira erythromos, S. oporaphilum, Myotis keaysi, Conepatus semistriatus, Sciurus granatensis, Heteromys anomalus, H. catopterius Nephelomys caracolus, Transandinomys talamancae and Proechimys guairae.

\section{DISCUSSION}

Records obtained here provide new data for the Sierra de Aroa (Handley 1976) and update the list of mammals from Yurubí National Park.
The documentation of these species represents $28 \%$ of 278 reported mammals in Northern Venezuela (Wilson \& Reeder 2005).

With respect to medium-large sized mammals of hunting interest such as peccaries ( $\mathrm{Pec}$ ari tajacu and Tayassu pecari), paca (Cuniculus paca), agouti (Dasyprocta leporina) and deer (Mazama americana and Odocoileus cariacou) among others, their use as food can be considered as occasional, but it can be transformed if the daily use by local residents results successful in their hunting activities. They hunt very often, but this activity does not represent their basic sustenance. Apparently, only Mazama americana, a large-sized mammal evaluated in "Data deficient" for Venezuela (Rodríguez \& Rojas 2008), was used in Yurubí National Park as food by local residents; the rest of mediumlarge sized mammals recorded in this study, and threatened in other localities of the country (Ochoa et al. 1995, Ochoa 2000), were apparently not hunted here.

Of carnivores defined in Venezuela within some threat category (Rodríguez \& Rojas 2008), Puma concolor (Near threatened), Panthera onca, Leopardus pardalis and Leopardus sp. (Vulnerable) would be species mostly affected in the study area, because to the fear of local residents with these cats. It is important to mention the definition of "surrogate species" for some taxa recorded in Yurubí National Park: Panthera onca is defined as "umbrella species" and Puma concolor as "flagship species". These species are used in ecosystem conservation programs in the Neotropics (Isasi 2011); however, in an occasional encounter with these cats in the study area, they can be hunted without any importance of their conservation status. Another taxon considered "flagship species" in Yurubí National Park was the tapir (Tapirus terrestris); this large-sized mammal apparently was not hunted in the study area according to interviews with local residents.

According to surveys, the following taxa were considered common in the forest and they were not used for any purpose: Didelphis marsupialis, Tamandua tetradactyla, Alouatta seniculus, Cebus olivaceus, Procyon 
cancrivorus, Conepatus semistriatus and Potos flavus.

Small mammals showed a high number of species and families for bats (Phyllostomidae, Emballonuridae and Mormoopidae), marsupials (Didelphidae) and rodents (Sciuridae, Heteromyidae, Cricetidae and Echimyidae), very close to values found in other localities of the Northern side of the country (Handley 1976, Ochoa et al. 1995).

There are few records for Transandinomys talamancae in the Sierra de Aroa (which Handley 1976, assigned to the Oryzomys "capito" complex), and this rodent together with Sciurus granatensis, Heteromys anomalus, H. catopterius, Nephelomys caracolus and Proechimys guairae were the only representatives of families Sciuridae, Heteromyidae, Cricetidae and Echimyidae in the evaluated vegetation types. Some researchers regarded Heteromys anomalus, as one of the most common terrestrial rodent of forests in Northern Venezuela from sea level to over $2000 \mathrm{~m}$ (Handley 1976, Valdez et al. 1984), but a recent taxonomic study (Anderson \& Gutiérrez 2009), has confirmed a new species (Heteromys catopterius), from populations previously ascribed to the anomalus complex.

This new species was found between 1500-1 940m (Anderson \& Gutiérrez 2009). This record in Sierra de Aroa, represents the first one for this rodent, and a substantial range extension to the West occurring from the West of the Depresión de Yaracuy, it is likely disjunctive from known records to the East.

It is noteworthy to mention the importance of Proechimys guairae, Heteromys catopterius and Nephelomys caracolus as endemic species to Northern Venezuela (Musser \& Carleton 2005, Anderson \& Gutiérrez 2009). In the present, these rodents have not been evaluated in threat categories defined in the country (Rodríguez \& Rojas 2008).

Phyllostomid bats such as Carollia perspicillata, Artibeus planirostris and Sturnira lilium were the most common and with higher capture frequencies, in agreement with other records in primary forests in Venezuela (Handley 1976,
Ochoa et al. 1995, Ochoa 2000). They commonly represent the dominant fraction in the understory of Neotropical forests (Ochoa et al. 1995, 2005), partly because of their very general food requirements (e.g., these bats consume fruits of understory and canopy plants like Piper spp., Ficus spp., Cecropia spp. and Solanum spp., Ochoa 2000); furthermore, there is no overlap in items consumed (Carollia is specialized in Piper, Artibeus in Ficus and Cecropia and Sturnira in Solanum, Ochoa 2000, Thies \& Kalko 2004); there is no overlap in flight patterns during the search of food (flights in understory for Carollia spp. and Sturnira spp., and understory and canopy for Artibeus spp., Soriano 2000); echolocation is less developed, making them easier to catch with mist nets, and another argument is related with capabilities to inhabit highly disturbed environments, as well as those in a pristine condition (Ochoa 2000).

Particularly in the evergreen forest, which had a primary condition, we observed forest Piper species in the understory, consumed mainly by Carollia spp. (Thies \& Kalko 2004), as well as the typical species of Ficus spp., which provide fruits throughout the year. Some bats captured in this inventory were considered strict frugivores (e.g., Artibeus spp., Carollia spp., and Sturnira spp.), using these resources as items of their diet (Kalko et al. 1996, Thies \& Kalko 2004).

An interesting record is the presence in the study area of 13 of the 20 species in the Cordillera de la Costa (Linares 1998) of bats belonging to the subfamily Phyllostominae. Bats captured in Yurubí National Park of this subfamily are considered rare and have low relative abundances (Ochoa 2000); their feeding strategies include insectivorous (e.g., Lonchorhina aurita, Lophostoma silvicolum and Mimon crenulatum), fruits consumers as an additional component to their diet of insects (e.g., Micronycteris spp., and Tonatia saurophila), pollen and nectar consumers (e.g., Phyllostomus discolor and P. hastatus) and small vertebrate consumers (e.g., Chrotopterus auritus and Trachops cirrhosus). 
In addition to their ecological preferences, which make their capture difficult (because these bats habit in primary forests and use a variety of habitats with different availability of food and shelter resources), they seem to be sensitive elements not tolerant to high disturbances in forests (Fenton et al. 1992, Ochoa 2000).

Another support of the primary condition of the vegetation inventoried was the absence of individuals of the common vampire (Desmodus rotundus) in sampled days. This vampire consumes only blood, with preference for the cattle, and often is considered a "damaging species" in localities with great disturbances (Fernández-Badillo \& Ulloa 1990). Although we did not captured Desmodus rotundus in the study area, local residents recognize it because sometimes their domestic animals suffer bite injuries.

Similarly, the capture of another vampire, Diphylla ecaudata, collected in the evergreen forest at $197 \mathrm{~m}$, indicates the primary condition of environments. This species unlike Desmodus rotundus, has been recorded mostly at elevations above $800 \mathrm{~m}$, in pristine forests in Venezuela (Handley 1976) and specializes in the consumption of vertebrate blood, with preferences for the avian one (Greenhall et al. 1984) from species that live in forested environments, making it a rare species to collect in disturbed areas.

The mammals of Yurubí National Park are an important component of the biodiversity of forests in the Cordillera de la Costa. Data and observations obtained in this inventory (e.g., endemism, mammals known as "surrogate species" threatened in Venezuela) give an important role at the Yurubí National Park, for the maintenance and conservation of ecosystems and local wildlife, threatened by human pressures of present times.

\section{ACKNOWLEDGMENTS}

Authors wish to thank the staff of the Museo de la Estación Biológica de Rancho (Francisco Bisbal and Javier Sánchez), for allowing us to review the material deposited at the museum and supported us in fieldworks (equipment loans); Hylda Siliet, Edward Camargo, Ivan Díaz, and Vicente Colmenares for all logistical support of lodging at both locations; the Departamento de Biología, Universidad de Carabobo, especially Héctor Silva, Antonio Pérez, Guillermo Flórez, Jorge Giménez †, Karen López, and Yoiber Mujica for their fieldwork supports, and Carlos Varela for his help in some identifications of botanical taxa, Robert Anderson for his suggestions and the Instituto Nacional de Parques INPARQUES-Yaracuy.

\section{RESUMEN}

En Venezuela, los mamíferos representan un importante grupo de la fauna con altas presiones antropogénicas que amenazan su permanencia. Enfocados en la necesidad de generar información de línea base que nos permita contribuir con la documentación y conservación de la riqueza de la fauna local, realizamos un inventario de mamíferos en el Parque Nacional Yurubí, localizado en el estado Yaracuy, Venezuela. Llevamos a cabo trabajos de campo en tres tipos de vegetación seleccionados: un bosque siempreverde a $197 \mathrm{~m}$., un bosque semideciduo entre $100-230 \mathrm{~m}$ y un bosque nublado a $1446 \mathrm{~m}$. Utilizamos trampas Victor, Sherman, Havahart y un sistema de trampa de caída para la captura de pequeños mamíferos no voladores y mallas de neblina para murciélagos. Adicionalmente, entrevistamos a los pobladores locales para el registro de mamíferos de porte mediano a grande junto con observaciones ocasionales directas e indirectas. Al menos 79 especies están presentes en el área de estudio, representando el $28 \%$ de la fauna de mamíferos registrada para el norte del país. Chiroptera (39 spp.), Carnivora (13 spp.) y Rodentia (9 spp.) fueron los órdenes con las mayores riquezas taxonómicas, coincidiendo con los resultados esperados en el Neotrópico. El bosque siempreverde obtuvo la mayor riqueza de especies $(n=68)$, con un esfuerzo de muestreo de 128 horas-malla, 32 baldes-día, 16 horas de observaciones y tres personas entrevistadas, seguida por el bosque nublado $(\mathrm{n}=45)$ con 324 horas-malla, 790 trampas-noche, 77 baldes-día, 10 horas de observaciones y una persona entrevistada. El valor más bajo de la riqueza fue en el bosque semideciduo $(n=41)$, con 591 trampas-noche, 15 horas-malla, 10 horas de observaciones y tres personas entrevistadas. Los datos y observaciones obtenidos aquí (e.g., endemismo, especies conocidas como "especies sucedáneas" amenazadas en Venezuela), le confieren al Parque Nacional Yurubí un papel importante en la conservación y mantenimiento de los ecosistemas y fauna local, actualmente amenazados por presiones humanas locales en la Cordillera de la Costa. 
Palabras claves: inventarios, mamíferos, Parque Nacional Yurubí, Sierra de Aroa, Venezuela.

\section{REFERENCES}

Alvarado, H. 2008. Aspectos estructurales y florísticos de cuatro bosques ribereños de la cuenca del Río Aroa, estado Yaracuy, Venezuela. Acta Bot. Venez. 31: 273-290.

Anderson, R.P. 2003. Taxonomy, distribution and natural history of the genus Heteromys (Rodentia: Heteromyidae) in Western Venezuela, with the description of a dwarf species from the Península de Paraguaná. Am. Mus. Novit. 3396: 1-43.

Anderson, R.P. \& E.E. Gutiérrez. 2009. Taxonomy, distribution, and natural history of the genus Heteromys (Rodentia: Heteromyidae) in Central and Eastern Venezuela, with the description of a new species from the Cordillera de la Costa, p. 33-93. In R. Voss \& M. Carleton (eds.). Systematic Mammalogy: Contributions in Honor of Guy G. Musser. Bull. Am. Mus. Nat. Hist. EEUU.

Bisbal, F.J. 1995. Mamíferos de la región pantanosa de los estados Monagas y Sucre, Venezuela. Acta Cient. Venez. 46: 288-293.

Bisbal, F.J. 1998. Mamíferos de la Península de Paría, estado Sucre, Venezuela y sus relaciones biogeográficas. Interciencia 23: 176-181.

Bisbal, F.J. 2008. Los vertebrados terrestres de las Dependencias Federales de Venezuela. Interciencia 33: 103-111.

Dávalos, L.M. \& A. Corthals. 2008. A new species of Lonchophylla (Chiroptera: Phyllostomidae) from the Eastern Andes of Northwestern South America. Am Mus. Novit. 3635: 1-16.

Delascio, C. 1977. Notas sobre la flora del Yurubí, Estado Yaracuy, Venezuela. Mem. Soc. Cienc. Nat. 37: 266-281.

Fenton, M.B., L. Acharya, L. Audet, M.B.C. Hickey, C. Merriman, M.K. Obrist, D.M. Syme \& B. Adkins. 1992. Phyllostomid bats (Chiroptera: Phyllostomidae) as indicators of habitat disruption in the Neotropics. Biotropica 24: 440-446.

Fernández-Badillo, A. \& G. Ulloa. 1990. Fauna del Parque Nacional Henri Pittier, Venezuela: Composición y diversidad de la mastofauna. Acta Cient. Venez. 41: 50-63.
Gannon, W.L., R.S. Sikes \& the Animal Care and Use Commite of the American Society of Mammalogist. 2007. Guidelines of the American Society of Mammalogists for the use of wild mammals in research. J. Mammal. 88: 809-823.

Gardner, A.L. 1988. The mammals of Parque Nacional Serranía de la Neblina, Territorio Federal Amazonas, Venezuela, p. 695-765. In C. Brewer-Carias (ed.). Cerro La Neblina: Resultados de la expedición 19831987. SUCAE, Caracas, Venezuela.

Gardner, A.L. 2008. Mammals of South America, Volume 1: marsupials, xenarthrans, shrews and bats. The University of Chicago, Chicago, EEUU.

Greenhall, A.M., U. Schmitdt \& G. Joermann. 1984. Diphylla ecaudata. Mamm. Species 227: 1-3.

Guerrero, R., R. Hoogesteijn \& P.J. Soriano. 1989. Lista preliminar de los mamíferos del Cerro Marahuaca, $\mathrm{T}$. F. Amazonas, Venezuela. Acta Terramaris 1: 71-77.

Gutiérrez, E.E. \& J. Molinari. 2008. Morfometrics and taxonomy of bats of the genus Pteronotus (Subgenus Phyllodia) in Venezuela. J. Mammal. 89: 292-305.

Handley, C.O., Jr. 1976. Mammals of the Smithsonian Venezuelan Project. Brigham Young Univ. Sci. Bull. Biol. Ser. 20: 1-91.

Hilty, S.L., J. Gwynne \& G. Tudor. 2003. Birds of Venezuela. Princeton University, Princeton, EEUU.

Helgen, K.M., R. Kays, L.E. Helgen, M.T.N. TsuchiyaJerep, C. Miguel-Pinto, K.P. Koepfli, E. Eizirk \& J.E. Maldonado. 2009. Taxonomic boundaries and geophraphic distributions revealed by an integrative systematic overview of the mountain coatis Nasuella (Carnivora: Procyonidae). Small Carn. Conserv. 41: 65-74.

Kalko, E.K.V., E.A. Herre \& C.O. Handley. 1996. Relation of fig fruit characteristics to fruit-eating bats in the new and old world tropics. J. Biogeogr. 23: 565-576.

Isasi-Catalá, E. 2011. Los conceptos de especies indicadoras, paraguas, banderas y claves: su uso y abuso en ecología de la conservación. Interciencia 36: 31-38.

Larsen, P.A., S.R. Hoofer, M.C. Bozeman, S.C. Pedersen, H.H. Genoways, C.J. Phillips, D.E. Pumo \& R.J. Baker. 2007. Phyllogenetics and phylogeography of the Artibeus jamaicensis complex based on cytochrome- $b$ DNA sequences. J. Mammal. 88: 712-727. 
Lentino, M. \& D. Esclasans. 2005. Áreas importantes para la conservación de las aves en Venezuela, p. 621-730, In K. Boylan \& A. Estrada (eds.). BirdLife International. Áreas importantes para la conservación de las aves en los Andes Tropicales: sitios prioritarios para la conservación de la biodiversidad. Quito, Ecuador.

Lew, D. \& R. Pérez-Hernández. 2004. Una nueva especie del género Monodelphis (Didelphimorphia: Didelphidae) de la Sierra de Lema, Venezuela. Mem. Soc. Cienc. Nat. 159-160: 6-25.

Lew, D., R. Pérez-Hernández \& J. Ventura 2006. Two new species of Philander (Didelphimorphia: Didelphidae) from Northern of South America. J. Mammal. 87: 224-237.

Lew, D., B.A. Rivas, H. Rojas \& A. Ferrer. 2009. Capitulo 6 Mamíferos del Parque Nacional Canaima, p. 153-179. In J.C. Senaris, D. Lew \& C. Lasso (eds.). Biodiversidad del Parque Nacional Canaima: bases técnicas para la conservación de la Guayana venezolana. Fundación La Salle de Ciencias Naturales and The Nature Conservancy, Caracas, Venezuela.

Lim, B.K., M.D. Engstrom, J.L. Patton \& J.W. Bickham. 2008. Systematic review of small fruit-eating bats (Artibeus) from the Guianas and a re-evaluation of $A$. glaucus bogotensis. Acta Chiropterol. 10: 243-256.

Linares, O.J. 1998. Mamíferos de Venezuela. Sociedad Conservacionista AUDOBON de Venezuela, Caracas, Venezuela.

Linares, O.J. \& B.A. Rivas. 2003. Mamíferos del Sistema Deltaico (Delta del Orinoco-Golfo de Paría), Venezuela. Mem. Soc. Cienc. Nat. 159: 185-262.

MARN. 2003. Inventario preliminar de fauna silvestre del Parque Nacional Juan Crisóstomo Falcón, Sierra de San Luis, estado Falcón. Serie Informes Técnicos ONBD/IT/420, Maracay, Venezuela.

MARN. 2005. Inventario preliminar de la fauna del Parque Nacional Dinira: estados Lara, Portuguesa y Trujillo, sector norte. Serie Informes Técnicos ONDB/IT/423, Maracay, Venezuela.

Mijares-Urrutia, A. \& R. Rivero. 2000. A new treefrog from the Sierra de Aroa, Northern Venezuela. J. Herpetol. 34: 80-84.

Molinari, J. 2007. Variación geográfica en los venados de cola blanca (Cervidae, Odocoileus), de Venezuela, con énfasis en $O$. margaritae, la especie enana de la isla de Margarita. Mem. Soc. Cienc. Nat. 167: 29-72.
Musser, G.G. \& M.D. Carleton. 2005. Superfamily Muroidea, p. 1086-1186. In D.E. Wilson \& D.M. Reeder (eds.). Mammals species of the world: a taxonomic and geographic reference. Volume 2. The Johns Hopkins University, Baltimore, EEUU.

Ochoa, G.J. 1986. Inventario preliminar de la mastofauna del tramo occidental de la Cordillera de la Costa. Informe Técnico. MARN-DGSIIA, Maracay, Venezuela.

Ochoa, G.J. \& S. Gorzula. 1992. Los Mamíferos del Macizo del Chimantá con algunos comentarios sobre las comunidades de las cumbres tepuyanas, p. 295-302. In O. Huber (ed.). Chimantá, Escudo de Guayana, Venezuela: un ensayo ecológico. Caracas, Venezuela.

Ochoa, G.J., C. Molina \& S. Giner. 1993. Inventario y estudio comunitario de los mamíferos del Parque Nacional Canaima con una lista de las especies registradas para la Guayana venezolana. Acta Cient. Venez. 44: 245-262.

Ochoa, G.J., M. Aguilera \& P.J. Soriano. 1995. Los mamíferos del Parque Nacional Guatopo (Venezuela): Lista actualizada y estudio comunitario. Acta Cient. Venez. 46: 174-187.

Ochoa, G.J. 2000. Efectos de la extracción de maderas sobre la diversidad de mamíferos pequeños en bosques de tierras bajas de la Guayana venezolana. Biotropica 32: 146-164.

Ochoa, G.J., M. O'Farell \& B. Miller. 2000. Contribution of acoustic methods to the study of insectivorous bat diversity in protected areas from Northern Venezuela. Acta Chiropterol. 2: 171-183.

Ochoa, G.J. \& M. Aguilera. 2003. Mamíferos, p. 650672. In M. Aguilera, A. Azócar \& E.G. Jiménez (eds.). Biodiversidad en Venezuela. Fundación Polar, Ministerio de Ciencia y Tecnología, Fondo Nacional de Ciencia, Tecnología e Innovación (FONACIT), Caracas, Venezuela.

Ochoa, G.J., M. Bevilacqua \& F. García. 2005. Evaluación ecológica rápida de las comunidades de mamíferos en cinco localidades del Delta del Orinoco, Venezuela. Interciencia 30: 466-475.

Ochoa, G.J., F. García, S. Caura \& J. Sánchez. 2008. Mamíferos de la cuenca del Río Caura, Venezuela: Listado taxonómico y distribución conocida. Mem. Soc. Cienc. Nat. 170: 5-80.

Ojasti, J., R. Guerrero \& O. Hernández. 1992. Mamíferos de la expedición Tapirapecó, estado Amazonas, Venezuela. Acta Biol. Venez. 14: 27-40. 
Rivas, B.A. \& M.A. Salcedo. 2005. Lista actualizada de los mamíferos del Parque Nacional El Ávila, Venezuela. Mem. Soc. Cienc. Nat. 164: 29-56.

Rodríguez, J. \& F. Rojas-Suárez. 1998. Las áreas protegidas estrictas y la conservación de la fauna venezolana amenazada. Acta Cient. Venez. 49: 173-178.

Rodríguez, J. \& F. Rojas-Suárez. 2008. Libro rojo de la fauna venezolana. Provita and Shell of Venezuela, Caracas, Venezuela.

Rodríguez-Olarte, D., A. Amaro, J. Coronel \& D. Taphorn 2005. Los peces del Río Aroa, cuenca del Caribe, Venezuela. Mem. Soc. Cienc. Nat. 164: 101-127.

Roze, A. \& H. Solano. 1963. Resumen de la Familia Caecilidae (Amphibia: Gymnophiona) de Venezuela. Acta Biol. Venez. 3: 287-300.

Sánchez-Hernández, C., M.L. Romero-Almaraz \& G.D Schnell. 2005. New species of Sturnira (Chiroptera: Phyllostomidae) from Northern South America. J. Mammal. 86: 866-872.

Soriano, P.J., A. Utrera \& M. Sosa. 1990. Inventario preliminar de los mamíferos del Parque Nacional General Cruz Carrillo (Guaramacal), estado Trujillo, Venezuela. Biollania 7: 83-99.

Soriano, P.J., A. Díaz de Pascual, G.J. Ochoa \& M. Aguilera. 1999. Biogeographic analysis of the mammals communities in the venezuelan Andes. Interciencia 24: $17-25$.

Soriano, P.J. 2000. Functional structure of bat communities in tropical rainforest and Andean cloud forest. Ecotropicos 13: 1-20.

Thies, W. \& E.K.V. Kalko. 2004. Phenology of Neotropical pepper plants (Piperaceae) and their association with main dispersers, two short-tailed fruit bats, Carollia perspicillata and C. castanea (Phyllostomidae). Oikos 104: 362-376.

Valdez, J., J. Silva \& J. Ojasti. 1984. Contribución a la biología del ratón mochilero (Heteromys anomalus) (Rodentia: Heteromyidae). Acta Cient. Venez. 36: 191-198.

Voss, R.S. \& S.A. Jansa. 2009. Phylogenetic relationship and classification of didelphid marsupials, an extant radiation of new world metatherian mammals. Bull. Am. Mus. Nat. Hist. 322: 1-177.

Weskler, M., A.R. Percequillo \& R.S. Voss. 2006. Ten new genera of oryzomine rodents (Cricetidae: Sigmodontinae). Am. Mus. Novit. 3537: 1-29.

Wilson, D.E. \& D.M. Reeder. 2005. Mammals species of the world: a taxonomic and geographic reference. Vol. 1 and 2. The Hopkins University, Baltimore, EEUU. 